\title{
ÉTICA EM JEAN BURLAMAQUI E O ENSINO CONIMBRICENSE DO DIREITO NATURAL
}

\author{
Eduardo Romero de OLIVEIRA ${ }^{1}$
}

- RESUMO: Apresentamos o tratado de direito natural Jean Burlamaqui, utilizado nos seminários e ensino de filosofia em Portugal, por volta de 1770. Nosso texto expõe as principais noções morais de sua teoria jusnaturalista, com objetivo de destacar como ela ajudou a configurar então os pressupostos para a reflexão política portuguesa.

- PALAVRAS-CHAVES: ética, direito natural, Jean Burlamaqui, Portugal (17501777).

Nosso texto examina algumas características da reflexão filosófica em Portugal, na segunda metade do século XVIII. Tomamos por hipótese que duas condições, uma institucional e outra, contribuíram para configurar o campo desta reflexão também no Brasil, no início dos Oitocentos. Esta configuração foi proposta a partir de um conjunto de tratados jusnaturalistas, que estabelece as diretrizes gerais para o ensino de Ética, dentro dos cursos de Filosofia, e do Direito Natural, nos cursos jurídicos. Há de se considerar portanto as teorias jusnaturalistas que foram então importantes ao pensamento português, e que se apresentam paralelas às considerações éticas dentro da Filosofia.

\section{O jusnaturalismo setecentista}

Ressalve-se que o estudo do direito natural tornou-se notório na Europa nos séculos XVII e XVIII, e particularmente em Portugal, e tomava por refe-

1 Professor Assistente Doutor no Departamento de Turismo da Unesp, campus de Rosana. Artigo recebido em mar/07 e aprovado para publicação em jun/07. 
rência os tratados de filósofos e juristas alemães (Samuel Pufendorf, Christian Tomasius, J. Heinécio, Christian Wolff). Com a reforma dos cursos jurídicos portugueses e de filosofia, suas obras tornaram-se oficialmente textos de referência jurídica e ensino, em Portugal, durante o ministério do Marques de Pombal (1750-1777) (cf. Mêrea, 1957, p.203-6; veja tb Falcon, 1982, p.394, p.438). A importância intelectual atribuída a elas não era menor do que aquelas produzidas por Hobbes e Montesquieu. Em especial, Pufendorf foi um dos autores de referência para a reflexão filosófica em Portugal. O que nos leva a pensar esta aproximação do pensamento político setecentista português com o jusnaturalismo de Pufendorf; em especial, as considerações do jurista alemão em torno de uma teoria do dever. Na primeira metade do século XVIII, os tratados jusnaturalistas alemães foram conhecidos em outros reinos europeus e colônias inglesas, tanto pela tradução francesa e comentários do jurista huguenote Jean Barbeyrac (1674-1729) quanto por textos de vulgarização do suíço Jean Burlamaqui (1694-1748). Na Europa, o próprio Rousseau teve acesso ao jusnaturalismo germânico através da tradução de Barbeyrac. ${ }^{2}$ Em Portugal, a principal obra de Burlamaqui, Principes du droit naturel (1747), foi traduzida em 1768 com o título de Elementos do Direito Natural. O texto foi adotado inicialmente no Colégio dos Nobres - uma instituição régia de ensino secundário para filhos de nobres e da burguesia ascendente, aberta nos anos 1760 - para ensino do Direito Natural, e depois também na cadeira de filosofia, em Évora. Devido à reforma curricular nos colégios Ordem Terceira dos Franciscanos, tornou-se o manual de Direito Natural no curso de filosofia da ordem - o plano da reforma foi modelo aos colégios das demais ordens religiosas em Portugal. Como conseqüência da aplicação extensiva deste projeto, os colégios de ensino secundário passam a ter uma cadeira de Lógica e Ética, exposta com rudimentos de direito natural e cujo texto de aula foi o texto de Burlamaqui. Em 1781, esta cadeira foi ampliada e passou a se chamar "Filosofia Racional e Moral". ${ }^{3}$ Enfim, nos anos 1770, o conhecimento jurídico e filosófico português passa a recorrer formalmente às noções e teorias da Jurisprudência alemã setecen-

2 Ver Rousseau, 1983, parte II, cap. 2. A propósito de uma análise comparativa entre Pufendorf e Rousseau, consulte-se o trabalho de Nascimento, 2000. Há estudos que colocam Rousseau como um "vulgarizador" na França das teses do jurista alemão, junto com Burlamaqui e das traduções de Barbeyrac, cf. Dufour, 1988, p.103. Além da repercussão na Europa, os textos de Burlamaqui, Pufendorf e Grotius foram utilizados também no curso jurídico em Harvard, nos Estados Unidos, para ensino de Direito Natural. O texto de Burlamaqui teve uma tradução norte-americana em 1752. A $5^{a}$ edição desta tradução, publicada em 1807, encontra-se disponível na Internet, pelo site <http://www.constitution.org/liberlib.htm>. Acesso: 27 maio de 2001.

3 Cf. Andrade, 1965. p.340, p.387-8. O compêndio adotado é a tradução portuguesa de um tratado de Heinécio, Elementos de Filosofia Moral, cf. Pereira, 1974, p.4. 
tista e do jurista suíço. A admissão desta obra no ensino filosófico e jurídico português leva-nos a considerar a hipótese de uma convergência entre sua reflexão ética e teorias políticas admitidas com a reforma pombalina.

No lugar do exame do seu sistema filosófico, estamos destacando um campo de reflexão filosófica que se definiu no reino português. Com a ressalva de que a discussão ética tinha sido formulada dentro da teologia até a primeira metade do século XVIII - em especial, nos tratados neotomistas de Francisco de Vitória, Domingo de Soto e Francisco Suarez. Temos neste final dos Setecentos uma reformulação da reflexão filosófica, quando esta se separa formalmente da teologia e, concomitantemente, algumas relações parecem se anunciar com aquela teoria do dever. Sendo o Principes utilizado como texto de aula nos seminários portugueses, esperamos entender o motivo de sua aceitação e rápida difusão. Pretendemos expor elementos da reflexão ética do jurista suíço, e em seguida aspectos do panorama intelectual em Portugal setecentista. Esperamos recompor assim a configuração intelecual que viabilizou a aceitação das idéias de Burlamaqui e ao mesmo tempo uma reflexão ética em Portugal setecentista.

Nossa investigação atenta para esta configuração para compreender como esta reflexão foi produzida: o lugar institucional em que ela se apóia; nas teorias e conceitos retomados; nas questões enfrentadas; nos pontos de conflito; e mesmo na eficácia obtida. Isto nos coloca o projeto de uma história da leitura filosófica, em que o discurso filosófico é considerado em função desta sua produtividade. ${ }^{4}$ Pretendemos contudo ir além de propormos uma narrativa histórica como um inventário e exposição de noções filosóficas. Diversamente, talvez se possa expor os vínculos, reativações ou divergências que um texto produz com relação a outro. Delineamos assim o campo efetivo de uma reflexão filosófica. Uma proposta evidentemente extensa e irrealizável nos limites deste artigo; porém, colocamo-la apenas como um ensaio sobre pensamento político setecentista. Por isso delimitamos nossas considerações ao texto de Jean Burlamaqui. Primeiro, apresentando alguns elementos que ajudem a vislumbrar considerações sobre ética normativa. Em seguida, identificar se houve noções e princípios no texto de Burlamaqui com as quais aquela reorganização do ensino no período pombalino estabeleceu conexões. Esperamos com isto expor o campo de investigação filosófica que foi efetivamente definido.

\section{Uma teoria da orientação das condutas}

4 Pensamos aqui nas considerações de Renato Janine Ribeiro, segundo as quais uma análise filosófica deve ser dedicada à eficácia política do discurso, de sua produtividade, cf. Ribeiro, 1985. 
Esbocemos primeiramente a argumentação de Burlamaqui em suas linhas gerais, para ressaltarmos depois alguns pontos. O jurisconsulto suíço propõe apresentar, numa primeira parte do Principes, as regras que orientam a conduta humana e que a natureza estabeleceu para que o homem alcance seu fim. A reflexão de Burlamaqui sobre a ação humana concentra-se numa pesquisa de regras primeiras de condutas, que deduz da natureza humana: o conjunto destas regras forma o Direito Natural. Assim, refletir sobre o Direito é examinar como o homem pode ser conduzido e para qual finalidade, deduzindo assim "o princípio de suas ações" (Burlamaqui, 1989, p.2). ${ }^{5}$ Burlamaqui identifica inicialmente que a natureza do homem pode ser apreendida pelas suas faculdades, que são os "poderes de agir" próprios da alma humana (idem, p.5). Destacando aquelas faculdades que são as mais importantes: a da vontade (o poder de determinar as ações), da liberdade (o poder da deliberação) e do entendimento ou razão (do conhecimento da natureza do homem e das coisas, para guiar sua vontade). Burlamaqui reconhece num segundo momento que o homem, por sua natureza, está em permanente busca da felicidade: a "satisfação interior" decorrente da posse de algo bom; isto é, tudo aquilo que é agradável à sua preservação, perfeição, conveniência ou prazer (idem, p.14). Afirmando que Deus criou o homem para a felicidade e perfeição. Ou melhor, se a felicidade é o fim da existência do homem, o homem a obtém pelo uso de suas faculdades, procurando por tudo que lhe traga alguma satisfação - a manutenção de sua vida, o estado de perfeição de suas faculdades, uma vantagem ou prazer. Burlamaqui expõe, num terceiro momento, os diferentes estados naturais do homem. Estes são os estados primitivos do homem e criados independentemente da sua ação. Burlamaqui subdivide assim entre os estados primitivos instituídos por Deus e outros advindos destes, quando os homens modificaram tais estados e estabeleceram outros por sua livre disposição (como a sociedade civil) (idem, p.42). Burlamaqui afirma aqui que os homens devem poder exercer suas faculdades nos estados em que vivem, para alcançarem sua felicidade: estão então exercendo seus direitos para a felicidade do homem, com aprovação e direção do entendimento (idem, p.70).

Um daqueles estados primitivos é o definido por Burlamaqui tomando o homem com relação a outros homens. O jurista admite que, por sua "incli-

5 Esta edição pode ser consultada no site <http://www.galica.bnf.fr>. Acesso: 27 maio de 2001. Apesar do texto de Burlamaqui ter tido ampla circulação desde fins do século XVIII e início do XIX, não localizamos nenhum original francês do livro ou sua tradução portuguesa setecentista nas principais bibliotecas ou arquivos brasileiros consultados, em São Paulo ou no Rio de Janeiro. Aliás, esta obra não foi também encontrada nem no acervo da antiga biblioteca do curso jurídico da São Paulo (atual Biblioteca da Faculdade de Direito da USP), apesar de uma edição francesa de 1821 constar de um inventário de obras, já no final do século XIX, cf. Catálogo, 1887. 
nação natural", os homens atraem-se mutuamente e vêm a se unirem para realizar algum fim comum (idem, p.38). Assim, os homens têm uma propensão à convivência social, tanto porque esta é uma disposição natural quanto também para buscarem sua felicidade comum e vantagem particular. Contudo, o jurista suíço ressalta que, se os homens vivem em sociedade, a livre atuação de cada um em sua busca da felicidade pessoal conduz a um estado de guerra. Para evitar a sua própria destruição, e em vista do exercício dos seus direitos, o homem precisa estabelecer regras de condutas sociais. Burlamaqui observa que apenas o exame racional das faculdades e dos estados permite deduzir alguns preceitos da natureza do homem, para que estes orientem assim a confecção das regras necessárias à convivência social. E, devido ao recurso a este método, podemos compreender o que Burlamaqui entende por leis naturais e o objetivo delas: estas são as regras de condutas deduzidas da natureza do homem e cuja observância preserva a paz e felicidade da sociedade (idem, p.108). Destas regras naturais é que o jurista propõe o método pelo qual se possa deduzir a instituição de leis civis. Mas Burlamaqui ressalva que por definição a lei é aquela regra instituída pelo soberano na sociedade civil (idem, p.77). E o soberano, por sua vez, é entendido como aquele ou aqueles que receberam a autoridade superior e o direito de comandar (idem, p.42). Burlamaqui considera aqui que o advento da união civil e a autoridade suprema são originalmente constituídos pelos próprios homens para sua defesa comum. As regras civis de conduta e a sua obediência conseguem conter também o egoísmo desmedido, a busca desmesurada de felicidade pessoal que ameaça a sociedade e a felicidade comum. As leis civis são instituídas tão somente pelo soberano, que por elas regulam as condutas dos homens. E por este modo a vivência em sociedade permite que os homens venham a obter sua felicidade. Enfim, as leis civis são aquelas regras instituídas no estado de sociedade civil, mas que guardam uma relação de concordância e dependência com as leis naturais ou regras de condutas tomadas da natureza humana. E junto com as leis civis, subsiste também a soberania - este direito de comando e desempenho de autoridade - para que se estabeleça e respeite uma proporção entre a procura de felicidade pessoal e a comum. Para Burlamaqui, não apenas as leis civis coexistem com a soberania, mas também ambas devem sempre se reportar às leis naturais: em concordância com a natureza, estado e fim último do homem.

Importa-nos particularmente que Burlamaqui procura conceber, a partir desta reflexão sobre a natureza moral do homem e da sociedade, um sistema de moralidade que permita dirigir suas ações ou as de outros homens em relação ao que é bom e justo. Ressalvamos que Burlamaqui entende "moralidade" a partir da idéia de mores: as livres ações dos homens, suscetíveis de direção e regra (idem, p.109). Tal idéia possibilita ao jurista propor 
um conjunto de regras ou leis naturais que permitem a avaliação das ações humanas. Por este sistema pode-se qualificar uma ação, seja com relação a Deus (uma ação boa) ou aos homens (uma ação justa). E se a lei natural refere-se ao estado e natureza do homem, remete-se também a uma regra cuja autoria está em Deus, como criador do homem. Além disso, a compreensão desta regra reside também em sua própria natureza, pois o seu conhecimento pode ser atingido pela "luz da razão" (idem, p.108). E a finalidade desta lei natural é o próprio fim último estabelecido na natureza do homem (a felicidade), e apenas a sua observância garante a obtenção de "paz e felicidade da sociedade". Assim, a origem, poder e objetivo da lei natural estão compreendidos na própria natureza do homem. Destaque-se com isto que, para Burlamaqui, o conhecimento das leis naturais e a avaliação das ações supõe a compreensão da natureza dos homens, mas dá acesso também à vontade de Deus (seus preceitos e desígnios inscritos na natureza humana).

O jurista suíço propõe um Direito Natural em função do seu exame das leis naturais e dos comentários sobre moralidade: tais leis naturais são, ao mesmo tempo, critérios para julgamento e regras de condutas, mas remetem também a preceitos divinos. A segunda parte do tratado de Burlamaqui se ocupa enfim dos princípios de direito natural, e pela qual os homens conhecem a vontade de Deus. E esta segunda parte interessa-nos particularmente para aprofundarmos nosso exame desta relação proposta pelo jurista suíço entre sua teoria do Direito Natural e uma doutrina religiosa. De modo geral, temos em Burlamaqui uma teoria jusnaturalista que se apresenta como uma reflexão filosófica sobre a natureza do homem. O jurista suíço procura, por meio do exame de seu estado e natureza, deduzir racionalmente os princípios pelos quais o homem deve se guiar para agir e julgar o que é justo. Mas este agir, porque há um fim que reside na sua natureza, deve estar voltado para o que é bom. Um fim que é sua satisfação pessoal, mas também remete a Deus, que criou o homem e marca seus desígnios na natureza humana. Assim, Burlamaqui constitui a teoria do direito natural como um sistema de moralidade, pelo qual concebe a devoção a Deus em termos de uma soberania divina e obediência a seus preceitos - o que explica sua adoção nos seminários religiosos portugueses. Enfim, a partir dos princípios expostos na primeira parte, como as idéias de soberania e de obrigação, Burlamaqui expõe uma argumentação sobre este sistema de moralidade civil que é arrematada, na segunda parte, por uma moralidade religiosa. 


\section{Alguns princípios de moralidade}

Existem quatro pontos a serem destacados nesta explanação que Burlamaqui fez sobre Direito Natural. Um primeiro ponto é noção de entendimento, concebida por Burlamaqui como uma principal faculdade do homem e também um princípio moral; e por isto, uma noção importante na reflexão de Burlamaqui. Ressaltamos aqui nem tanto o poder de conhecer a verdade, tomado pelo jurista como uma das características desta faculdade, mas a sua capacidade de direção moral em vista do aperfeiçoamento do homem. ${ }^{6}$ O que acentuamos, isto sim, é que a razão foi concebida pelo jurista como um poder interior, capaz de obrigar e dirigir as condutas. Se os homens são criaturas racionais e livres, eles podem exercer sua liberdade em vista do seu estado e destino, dirigindo seus atos para sua própria felicidade. Vivendo porém em sociedade, a independência do homem conduz à "libertinagem", pois o homem toma como princípio de conduta o capricho ou a paixão. Se estivesse livre para agir conforme seus instintos, o homem seria portanto uma "besta feroz" (idem, p.135). Mas ele pode prevenir isto por meio da "luz da razão", que é uma faculdade interna ao homem com poder de suspender suas próprias ações. Através do entendimento, o homem investiga a sua própria natureza e busca assim os meios para alcançar a sua felicidade; não se deixando guiar pelo instinto. Por isto é preciso recorrer às leis naturais e aos vínculos morais, para com elas estabelecer a ordem e a justiça por todo o corpo político. Burlamaqui comenta que também Deus, "infinitamente sábio e melhor que nós, deve estar indubitavelmente persuadido do mesmo método" (ibidem). Assim, as leis naturais foram dadas por Deus para aperfeiçoarem a natureza do homem, prevenir os abusos e "moderar" a busca particular de satisfação (idem, p.131). A moderação dos instintos e das paixões é assim possível, como resultado da observância das leis naturais. Uma contenção dos instintos baseada na restrição da liberdade - mas não na sua exclusão, visto que ela é essencial, segundo Burlamaqui, para o pleno exercício dos deveres (idem, p.74). O homem precisa portanto, pelo uso da razão, restringir a sua plena liberdade para que todos possam fazer uso de seus direitos e assim procurarem cada qual sua felicidade. Além disso, o estabelecimento das leis naturais se apoia no cuidado

6 Reconhecemos que, para o jurista suíço, esta busca pela perfeição supõe também a investigação da verdade pela razão. De modo que a sua noção de direito supõe uma "reta razão", em que certeza e direção da conduta funcionam juntas. Contudo, apenas outro estudo, que examinasse particularmente esta faculdade de entendimento em Burlamaqui, permite averiguar como se procede a esta pesquisa da verdade. Para então expor a relação desta pesquisa com a sua teoria de direito natural. Restringimos porém o exame da faculdade de entendimento apenas no que importa ao nosso objetivo de expor o sistema moral de Burlamaqui. 
da alma, mais do que no corpo, pois é nela que o homem sente aquela "satisfação interna" (a felicidade). A perseverança da alma segue assim os conselhos da sabedoria, guiando-se por ela em vista de alcançar a virtude e a perfeição. Uma moderação que é realizada pelo entendimento, pelo qual os homens se aperfeiçoam.

Notemos, como um segundo ponto, que Burlamaqui propõe deduzir os princípios de Direito Natural do exame da natureza e do estado atual do homem. No exame da natureza do homem, Burlamaqui afirma ter Deus "criado o homem para a felicidade" (idem, p.136). Por isto o Criador "implantou" nele uma "insuperável inclinação" para o que lhe é bom e agradável (a felicidade). Uma inclinação é algo que está sempre presente, pois Deus incutiu-o em cada homem, como um impulso moral inato - tais são os instintos de amor-próprio e da auto-preservação. Assim o amor-próprio é posto pelo jurista suíço como sendo um móbile primeiro de todas as nossas ações, pois fixa em nós o desejo de felicidade. Ao mesmo tempo, o jurista compreende as leis naturais pelo exame do estado do homem, e particularmente aquelas leis relativas aos deveres mútuos e que tem a sociedade como objeto. Daí Burlamaqui propor-se a descobri-las pelo exame do estado atual das coisas - o que apresenta como seu método de investigação. O jurista parte do estado social atual para deduzir um princípio da lei natural. Examinando deste modo a condição presente do homem, que é a vida em sociedade, Burlamaqui retira algumas conclusões. Em primeiro lugar, examinando este estado dos homens, o jurista observa o estado de fraqueza do homem, seja na infância ou na velhice. E sua fragilidade física solicita o cuidado e permanente auxílio de outrem. O jurista deduz desta condição de carência física o primeiro motivo pelo qual a sociedade é necessária aos homens. Em segundo lugar, Burlamaqui examina as faculdades humanas para explicar como delas se origina a sociedade. Exemplifica que a fala permite a expressão do pensamento, o qual não há outro uso a não ser em sociedade. Em terceiro lugar, o jurista toma os instintos morais ou inclinações humanas para avaliar as suas conseqüências para o estado presente do homem. Observa que um destes instintos é o sentimento de compaixão pela dor do outro, que nos leva ao seu imediato socorro; o outro, a benelovência, é a gratidão e estima pelo recebimento de um benefício. Burlamaqui deduz por estes comentários que nossas inclinações humanas encontram prazer no estado de sociedade. O método de análise é o mesmo por todo o texto: o estado atual é o ponto de partida da análise do homem. Neste estado encontra o testemunho de uma lei natural; mas ele é também a prova de que o desígnio divino se realizou.

Enfim, devido a sua constituição, faculdades e instintos, o homem tenderia sempre para o estado social. E do que pode concluir e afirmar um princípio de direito natural: a sociabilidade. Burlamaqui considera que 
Deus estabeleceu este princípio em nossa natureza com o exclusivo propósito de conciliar nossa felicidade particular com a dos outros. Evitando com isto que os homens se deixem guiar tão somente pelo amor-próprio; o que destrói as vantagens da sociedade, caindo-se num estado de guerra. O homem é "obrigado" pela natureza das coisas a buscar sua felicidade; ou, o que toma como equivalente, o homem fora "sujeitado" por Deus a viver em estado social (idem, p.136). Considera esta equivalência porque, ao mesmo tempo em que a sociabilidade é resultado da natureza humana, ela expõe também um desígnio divino. Se Deus "implantou" o amor-próprio, colocou também a benevolência como uma inclinação oposta (idem, p.163). E ambas as inclinações foram "gravadas em nossos corações", para atuarem em conjunto em vista da felicidade humana. Burlamaqui reconhece portanto que a sociabilidade é um princípio moral, e que era pertinente tanto à natureza humana quanto à vontade de Deus. E devido ao princípio de sociabilidade, a procura de vantagem particular fica subordinada ao bem comum. O que permitiu a Burlamaqui deduzir várias leis naturais, inclusive a de que "o bem público deve sempre ser a regra suprema" (idem, p.163).

Um terceiro ponto relevante em Burlamaqui, na sua explanação sobre o Direito Natural, é sua argumentação sobre o estabelecimento do que é justo. Burlamaqui destaca que aquelas inclinações inatas do homem se manifestam na procura pelo bom e em evitar o mal (o instinto de compaixão ou o de benevolência) (idem, p.142-4). Mas existe também uma segunda apreensão possível do que é moralmente bom: através do discernimento do bom. Este segunda forma de apreensão, afirma o jurista suíço, é a razão e a reflexão, que produzem o julgamento das ações. Burlamaqui entende que a apreensão de uma justiça advém então do recurso conjunto ao instinto e à razão: aquele dá a primeira constatação, e outro a verifica e prova. O entendimento torna possível a todo homem verificar os instintos, deduzir-lhes os princípios e aplicá-lo a todos os casos (idem, p.145-6). Se os instintos e a faculdade do entendimento fazem parte da natureza do homem, são encontrados em todo homem. Portanto as leis naturais são conhecidas por toda a humanidade e comuns a todos por sua própria natureza. O direito natural é assim um direito do Homem: tanto por ser um conjunto de regras comuns a todos os homens, quanto um conhecimento generalizado por natureza e aplicável a todas às ações humanas.

Mas Burlamaqui ressalva não supor que estas leis sejam inatas, como se elas fossem "impressas em nossas almas desde o primeiro momento de nossa existência" (idem, p.174). Primeiro, porque tais leis correspondem à natureza e ao estado presente do homem. Sendo agradáveis à nossa natureza, são proporcionais ao grau de entendimento que o homem possui. Daí que tão logo estas leis forem sendo manifestadas, nós as aprovamos. E porque nos acostumamos a estas leis desde a infância, acreditamos terem nas- 
cido conosco. Portanto o direito natural não é inato aos homens, mas apenas conforme a nossa constituição humana - correspondente aos seus instintos e razão, apropriado a sua natureza e condição presente. Baseado naquelas considerações sobre o discernimento e nestas ressalvas, Burlamaqui observa que o entendimento e instinto humano permitem tanto estabelecer para cada homem o que é justo para as próprias ações, quanto é único meio possível de se propor as leis justas e convenientes a todo o corpo social. O que merece destaque é que Burlamaqui deduz, deste exame da natureza humana e do direito natural, um princípio fundador da sociedade: "todas as criaturas de uma mesma espécie, nascida com as mesmas faculdades para viver em sociedade, partilhando as mesmas vantagens, possuem um direito igual e comum" (idem, p.163). Eis então, para Burlamaqui, um princípio primeiro da sociedade: a igualdade.

Além disso, esta compreensão do justo cria, da parte do próprio homem que atinge esta compreensão, uma "necessidade razoável" de obedecer às leis do Direito Natural (idem, p.71). Tais leis são conformáveis às nossas idéias, agradável à natureza do homem, satisfatória ao estado social e apreensível enquanto uma justiça universal. Se o recurso ao instinto e ao entendimento permite-nos compreender os princípios da lei natural, discernimos portanto uma regra universal e útil. E todas estas características das leis naturais são as condições que Burlamaqui definiu como próprias a um princípio de obrigação: um preceito de conduta das nossas ações estabelecido pelo entendimento, e por isto obrigados internamente a seguir esta regra. Somos "obrigados" assim a considerar nós mesmos como "naturalmente iguais" (idem, p.163). E Burlamaqui vai além, apoiando-se no entendimento racional do Direito Natural para deduzir a soberania divina. Se as leis naturais derivam da natureza humana, que foi criada por Deus, portanto o Direito Natural decorre indiretamente da vontade de um ser superior. Esta soberania divina é assim uma vontade divina que age "indiretamente" porque o faz através da natureza humana, particularmente na razão humana. Daí a relevância que Burlamaqui atribui à faculdade do entendimento, que é assim um "oráculo interno" sobre o que bom e justo: pois "a linguagem da razão é a de Deus mesmo" (idem, p.138-9). E mais importante, uma afirmação do justo que é satisfatório a Deus e agradável a nós mesmo. Deste Criador estamos assim inteiramente dependentes; e o entendimento apreende as leis e impõe-nos internamente a obrigação de observála. A compreensão das leis naturais, e com elas o exame das perfeições divinas, proporcionam as "impressões" que nos levam ao infinito respeito. O entendimento é o que produz uma sensação interior, a qual nos obriga internamente a obedecer às leis naturais e apresenta-se como um conjunto de sentimentos (amor, medo e respeito). Deste modo, a soberania de Deus tem no entendimento um instrumento moral de reforço, que promove inter- 
namente a obrigação de obedecer a Deus. Através do entendimento, a obrigação interna produz este sentimento "gravado em nossos corações" que é o amor e respeito a Deus.

Há ainda um quarto e último ponto relevante em Burlamaqui sobre sua teoria do Direito Natural. A autoridade do Direito Natural está assentada assim na força desta aprovação interna da razão. E pelo entendimento se reconhece tanto que Deus é o autor destas leis naturais, quanto nos coloca a obrigação de agir conforme estas mesmas leis. Com isto Burlamaqui procura afirmar o direito de soberania de Deus sobre suas criaturas. Mas a obediência a este Direito Natural (a vontade manifesta de Deus), depende também de impor-se uma obrigação externa e relativa portanto à autoridade divina. Esta obrigação externa, Burlamaqui deduz da imortalidade da alma. Burlamaqui sustenta que devemos a obedecer à soberania de Deus, devido à dependência do homem, porque Deus é o criador do homem, de sua natureza e de todas as coisas. Neste poder de criar fundamenta-se a soberania de Deus sobre tudo e todos. Estamos por isto obrigados a obedecer às leis da natureza e utilizá-las para dirigir nossa conduta em nossa busca de felicidade. Podemos então premiar ou condenar a nós mesmos com o nosso livre modo de agir. E a sanção do Direito Natural decorre da imortalidade da alma, pois a punição pela desobediência destas leis vem na vida futura. Em resumo, a autoridade do Direito Natural advém da aprovação interna do homem e da busca de sua felicidade pessoal. E estas obrigações internas somam-se com uma obrigação externa: sanção na vida futura da alma, pela escolha do homem em seguir ou não os preceitos naturais. A idéia de imortalidade da alma dá ao sistema proposto por Burlamaqui a sanção do prêmio e punição, da felicidade espiritual ou purgação.

O entendimento e imortalidade da alma são portanto dois pontos de apoios do Direito Natural, segundo Burlamaqui, capazes de impor às ações humanas a obrigação de sua obediência. Através do primeiro apoio, o entendimento, Burlamaqui entende que a obediência à lei deve ser produzida por uma "consciência decisiva": com prontidão, uma atitude voluntária e prazerosa (idem, p.225). A qual decorre assim de um consentimento e uma vontade livre, que se dispõe por si mesma em obedecer. E pelo segundo ponto, a imortalidade da alma, os homens podem observar que é a sua própria felicidade que está em jogo: sua satisfação corporal, o uso de seus direitos deve ter em vista a promoção de um estado de ordem e perfeição da alma, resultante da aplicação do Direito Natural. Donde a obediência às leis naturais se torna o esforço de uma virtude, que é também manifestação de respeito a Deus, cuja vontade está expressa nestas leis naturais. Mas esta obrigação de obediência é a ratificação, segundo Burlamaqui, de um "sistema moral", "um sistema de criaturas inteligentes" (idem, p.279-80). Isto é, um sistema em que um ser livre e inteligente é "induzido a fazer uso ra- 
zoável de suas faculdades, em vista de sua felicidade". O dever de obedecer às leis apresenta-se assim fundamentada na liberdade e na razão. Ao mesmo tempo, Burlamaqui concebe com isto uma moral filosófica que se converte numa doutrina religiosa, quando o Direito Natural vem a ser confirmado pela revelação, que é a doutrina cristã (idem, p.295-6).

Em resumo, nesta segunda parte do Principes, Burlamaqui procura demonstrar que apenas a observância das leis naturais garante a preservação, aperfeiçoamento e felicidade dos homens, tanto públicas quanto privadas. Afinal, Deus criou o homem para a felicidade, e por isto obrigou-o a viver em sociedade. E através do exame da sua natureza e do estado das coisas, o homem alcança a compreensão de leis naturais e é convencido da bondade de Deus. Este conhecimento sobre o Direito Natural, para Burlamaqui, torna perceptível ao homem que tudo o que possui decorre de Deus e da sua vontade. A Jurisprudência é concebida assim como uma ciência das leis naturais, examinando a natureza do homem e dela depreendendo os desígnios de Deus; e, concomitantemente, é uma arte de fazer, explicar e aplicar à lei civil aquelas leis naturais. Com esta reflexão sobre os princípios de um Direito Natural, Burlamaqui pretende sustentar a lei divina (da qual decorre a leis naturais) e a soberania de Deus sobre os homens e as coisas. E se os homens podem conhecer tais leis pela luz da razão, ao investigarem seu estado e natureza, conseqüentemente estão obrigados a obedecer ao supremo poder de Deus sobre eles. As leis naturais permitem estabelecer portanto a absoluta soberania de Deus e a ilimitada dependência humana para com o ente divino. Sendo as leis naturais compreensíveis aos homens, por meio delas aprendem a amar a Deus e respeitá-lo.

\section{A elaboração de um jusnaturalismo cristão}

O que procuramos destacar, neste rápido exame do texto de Burlamaqui, foi um conjunto de conceitos morais e políticos: liberdade e decisão racional; a sociedade produzida pelo consentimento, fundada na liberdade e na igualdade; com objetivo de preservação e vantagem, tanto particular quanto comum; e governada por um poder soberano. Todo este conjunto de conceitos foi acionado por Burlamaqui para conceber uma teoria de Direito Natural. Em primeiro lugar, os homens são, para Burlamaqui, seres racionais e livres. Ou dizendo de outro modo, eles são capazes de vontade, decisão racional e liberdade de ação como faculdades ou poderes naturais ao ser humano. E estas capacidades ou faculdades naturais devem ser permitidas a todo homem exercer, porque lhe possibilita a obtenção de sua satisfação pessoal - a felicidade, que é o fim último do ser humano. 
Em segundo lugar, a sociedade sustenta-se na aprovação racional entre os homens, seres naturalmente iguais, para que todos os homens possam exercer seus direitos e alcançarem sua felicidade. Instituem-se então os direitos ou leis civis para regulamentar as ações de todos aqueles que vivem em sociedade, para que todos possam exercer seus direitos, que os abusos e crimes sejam contidos ou punidos. A sociedade fundamenta-se portanto - seguindo o raciocínio de Burlamaqui - na decisão racional dos próprios homens, que sendo iguais, estabelecem e obedecem as leis civis para um fim comum de vantagem e sua preservação. Em torno das idéias de consentimento e de ação racional, vários pensadores conceberam diferentes conceitos de contrato ou pacto social: Hobbes, Pufendorf, Locke, Rousseau. Assim operou também Burlamaqui. Este jurista suíço entendia que a sociedade era uma "instituição divina" porque Deus colocou "inclinações naturais" nos homens, dirigindo-os à mútua assistência e gratidão (GoyardFabre, 1988, p.38). Em outras palavras, a sociabilidade é própria da natureza humana - como são também as faculdades da vontade, da liberdade e da razão. Aqui é o seu "estado original", criado por Deus. Os homens exercem em seguida estas capacidades naturais para instituir a sociedade civil e o poder político; onde eles se subordinam a uma autoridade suprema - exceto em sua igualdade e independência (idem, p.42). E para o fim de "defesa comum", compõem um "corpo nacional", "governando pela vontade daquele ou daqueles a quem conferiram a autoridade". Tem-se então um "estado adventício", produzido pelo "consentimento humano"; um estado que modificou o "estado original" por meio da liberdade natural do homem. Eis aqui a concepção de pacto social feita por Burlamaqui.

Em terceiro lugar, o poder político é assim concebido como uma condição decorrente da própria sociedade: a soberania, entendida como um direito de comandar a sociedade. A soberania é um poder uno e supremo que se exerce sobre toda a sociedade, mantendo sua coesão e a ordem social. E autoridade deste direito supõe a obediência voluntária, mas também uma obediência externa, que advém da punição ou a recompensa. Enfim, a idéia de soberania exposta por Burlamaqui coloca-a como essencialmente vinculada à sociedade e aos homens que nela vivem: garante a felicidade destes, desde que a sociedade seja sempre preservada e superior às vantagens privadas.

Ao mesmo tempo, este jusnaturalismo setecentista concentra-se no estudo do homem, e parte deste estudo para estabelecer a crença em Deus. Os homens amam a Deus quando conhecem seus desígnios (através da lei natural) e poder (autoridade divina) - ou através da piedade. O movimento da razão e compreensão produz a obrigação de obedecer. E da compreensão das leis tem-se a percepção da justiça, o que contribui para cristalizar 
um sentimento do amor e o respeito a Deus, resultando na obediência ao ser divino. Mas a obrigação resulta também da autoridade divina, decorrente da suposição de vida futura e da ameaça de punição. Burlamaqui compõe assim um sistema de moralidade religiosa, apoiado nas mesmas idéias pelas quais deduziu os princípios de direito: o uso da liberdade; a felicidade como fim do homem; a predominância da faculdade do entendimento sobre as outras faculdades que o homem possui; a compreensão de leis e o destaque à obrigação. Destes princípios o jurista deduz a soberania divina. Se o homem deve sujeitar-se à vontade de Deus, para alcançar a felicidade de sua alma; em contrapartida, este funda a soberania para que, através dela, o homem alcance sua felicidade temporal (a preservação de sua vida, a segurança na possessão dos bens e propriedade). E apenas a manutenção da ordem social pode ajudar a garantir esta felicidade pessoal, com o bem-estar de cada indivíduo, a tranqüilidade das famílias e a prosperidade dos estados. A religião, a felicidade pessoal de cada homem e felicidade da sociedade surgem assim como interligadas nos princípios de direito natural de Burlamaqui (Burlamaqui, 1989, p.167-70). E o exercício do poder soberano é não apenas justificado, mas tem como única eficácia a obrigação de obediência. Dentro deste sistema proposto por Burlamaqui podemos identificar o amor de Deus. Burlamaqui concebe uma sociedade civil estabelecida por consentimento e que é uma vontade racional de cada um. Mas a razão que consente também produz um sentimento interior de respeito, e que produz a submissão do súdito e do devoto: o amor. Temos em Burlamaqui uma teoria política que supõe o sentimento do amor como parte de uma relação entre governantes e súditos, mas sendo aquele sentimento produzido por uma disposição racional e voluntária do homem.

A idéia de amor apresentava-se ainda no século XVII como uma concepção religiosa, tomada em função de uma noção de amor divino, em que a justiça de Deus é imanente aos homens: "conservan la ley natural en su corazón", diz o teólogo jesuíta Francisco Suarez (Suarez, 1975). Esta dimensão de sujeição amorosa, relativa ao governo religioso, pode ser aprofundada e uma extensa reflexão pode ser desenvolvida sobre a noção de amor divino em tratados teológicos dos Seiscentos - particularmente num teólogo como Suarez, cujas orientações de direito canônico predominaram em Portugal então. Para Suarez, a obrigação política está vinculada a uma pesquisa da verdade (pelo conhecimento racional na natureza dos homens, e que nela se revela como derivada de uma lei eterna e divina). Toda lei civil deve, por princípio, estar conforme a lei natural, cuja existência é externa aos homens porque referente a uma lei eterna e divina. Todo homem está obrigado no seu foro interno a obedecer às leis naturais enquanto expressando a verdade de Deus, e sendo por isto leis justas. E está obrigado por consciência a sujeitar-se às leis justas porque está moralmente impedido de desobede- 
cer à vontade de Deus. Portanto, uma lei civil apenas tem força de lei desde que seja conforme a lei natural; assim a lei civil é igualmente justa. Isto impõe ao homem uma obrigação à sua consciência, pelo qual ele deve agir tão somente conforme a toda lei que seja expressão da vontade de Deus. Tal conformação da conduta do homem é, para Suarez, um produto de sua própria vontade livre; mas a obediência ou não desta lei civil deriva do direito natural. Deste modo, o jusnaturalismo jesuítico coloca-se ainda como uma investigação onto-teológica; isto é, se os princípios do direito natural são leis eternas e universais relativas a Deus, estabelecer os fundamentos teóricos destas leis naturais equivale a conhecer o ente divino e o universo que ele criou.

Em função daquele princípio de obrigação, o próprio Suarez explica que a obrigação do amor a Deus aplica-se apenas aos preceitos relativos à caridade, e é plenamente alcançada tão somente pela graça. Isto porque este amor a Deus não pode obrigar à obediência dos demais preceitos ou leis naturais, mas tão somente no exercício da caridade. Aliás, afirma Suarez, a obrigação de amar a Deus é um preceito natural, e enquanto tal deve ser obedecido por si mesmo (a obrigação de amar), independente do seu objetivo (amar a Deus). "La finalidad de un precepto no cae dentro del precepto" (Suarez, 1979, p.177). Ainda que não se alcance o seu fim, o importante para Suarez é que se obedeça ao preceito e a ação esteja conforme a ele: "de forma que ésta sea constantemente y por propia naturaleza una especie de regla del bien obrar" (idem, p.176). A obrigação não exclui as virtudes cristãs (o amor a Deus, por exemplo), mas a lei natural não precisa destas virtudes para ser obedecida. O homem não precisa ser virtuoso para obedecer aos preceitos de Deus e amá-lo. Ao invés, por obedecer à lei natural, o homem age como se estivesse orientado e dirigido pela virtude de amor divino. Suarez apresenta sob este aspecto uma teoria de direito natural cujo princípio fundamental de seu jusnaturalismo (a obrigação política) é de que todo preceito deve ser obedecido, desde que justo, e independentemente se o propósito declarado pelo preceito seja alcançado. ${ }^{7}$ O próprio ato de obedecer e agir conforme as leis naturais é portanto exercitar a virtude declarada.

7 Para a importância da idéia de obrigação em Suarez vide ABRIL, 1977, p.XLVII . Admite-se que uma teoria do dever subsiste em Pufendorf, porém a hipótese que colocamos aqui é que Suarez teria formulado sua reflexão jusnaturalista já em função de um princípio de obrigação política. Esta hipótese ratifica o lugar e a importância de Suarez na filosofia moderna, junto a Hobbes, Pufendorf, Locke e Rousseau. Cf. idem, p.XLIX. Contudo, ressalvamos que o teólogo reporta este princípio à obediência a Deus, por meio da lei natural. Suarez concebe assim uma teoria do dever, evidentemente distinta por exemplo daquela de Pufendorf. Para um exame da teoria de direito natural de Suarez, consulte-se Mêrea, 1917. 
Dentro desta teoria de direito natural, o Rei que legisla conforme a lei natural não precisa ser virtuoso e nem o súdito obedece por virtude cristã, mas porque está obrigado a obedecer toda lei civil que está fundamentada numa lei natural. Obrigar os súditos é sempre o efeito imediato e intrínseco de toda lei civil fundamentada numa lei natural. Se o reconhecimento desta lei passa por uma investigação própria da teologia, apenas os teólogos podem estabelecê-la. E se a ação do Rei infringir uma lei natural, o Papa pode legitimamente "aconselhá-lo" a se corrigir. A teoria do direito natural proposta pelo teólogo jesuíta admite que as decisões ordinárias cabem a cada jurisdição (civil ou eclesiástica) e devem ser obedecidas, mas coloca o poder papal como a instância última de decisão temporal. A relação entre o Rei e seus súditos é formulada assim em termos de um dever de obedecer, em que este conceito político remete à idéia de uma obediência necessária às leis divinas e independentes da existência humana. ${ }^{8}$ Estas são algumas das principais conseqüências da teoria política do direito natural formulada por Suarez.

Nos anos 1760, em Portugal, este princípio de obediência política concebido por teólogos jusnaturalistas neotomistas como Suarez, foi apropriado por uma teoria de direito divino que buscava legitimar o poder régio. Um princípio de obrigação proposto agora por outra argumentação teológica e usado contra aquele jusnaturalismo de Suarez. Observamos isto nesta obrigação que impõe mais fortemente quando se trata de um poder real concebido como vindo diretamente de Deus, como defende o panfleto antijesuítico Dedução Cronológica e Analítica (Silva, 1768). Ou ainda panegírico da época, como o reverendo João de Sousa Tavares (Castello, 1974, p.264): "um monarca que não conhece superior na terra, escolhido e conservado por Deus, de quem recebe todo o poder e jurisdição". Temos então o monarca feito "vigário de Cristo na terra", aquele que é o representante na terra, "em imagem e semelhança", de Jesus. E cuja obrigação de obedecer esta lei humana vem diretamente de Deus. Então, o poder real baseado nos exercícios religiosos de sujeição remete-nos ao amor devoto, que supõe uma justificativa exterior e superior ao homem que o obriga a obedecer ao Rei: "dos vassalos o amor a tudo obriga", diz frei Antonio da Neves quando dos festejos cariocas por ocasião do casamento de D. Maria I (idem, p.320). A onipotência do amor condiciona a obediência, tanto quanto esta obediência dos sú-

8 Hobbes ataca justamente as conseqüências políticas desta proposição, para estabelecer a soberania como fundamento da sociedade. Janine Ribeiro observa que no lugar de uma relação entre os súditos e o Rei baseado no afeto, Hobbes propõe uma relação contratual: baseada na decisão racional e no consentimento daquele que é governado. Ribeiro, 1984. p.150. Com isto Hobbes pensa que uma política fundada no amor é contrária a outra, baseada na razão, e que possibilita um contrato fundador da soberania. 
ditos confirma o amor devido à rainha. A obediência amorosa é interna e necessária, por isto se diz "imperiosa".

As proposições de Burlamaqui apresentam outra concepção de sujeição política, que está inserida numa teoria de direito natural centrada no homem e não mais em Deus. Em contrapartida, a teoria de Burlamaqui não deixou de reelaborar dentro dela a devoção religiosa; e com ela, propôs também outra noção de amor divino. Esta teoria jusnaturalista redefinida por Burlamaqui não apenas é admitida como uma teoria política passível de ratificar o poder régio português, mas contém também uma ética admissível com a doutrina católica. E mais, uma ética que propõe também uma noção de amor coerente com a idéia de soberania, porque ambos se reportam a um princípio de obrigação às leis naturais. Em fins do século XVIII, este princípio de obrigação propõe a obediência como uma submissão a uma lei natural, própria da dimensão humana e por meio da faculdade do entendimento. A noção de amor define-se então em função do princípio de obrigação jusnaturalista, ou mais propriamente nos estudos jusnaturalistas definidos pela reforma pombalina - junto com a adoção de tratados de Pufendorf, Grotius, Wolff e vários outros jusnaturalistas alemães. Este amor é assim um sentimento de sujeição entre soberano e súditos, promovido por uma disposição interior que obriga a obedecer às leis régias (expressão racional de leis naturais). Uma idéia de amor que pode ser perfeitamente reativada pelo compromisso amoroso entre o Rei e os súditos. Portanto, também é possível falar-se em amor ao Rei, já no final daquele século em Portugal, como uma concepção moral e também jurídica, mas não propriamente teológica. Isto porque se trata ainda de propor uma obrigação política; contudo, um sentimento amoroso decorrente da aceitação de leis fundamentadas num direito natural, que reproduzem a própria natureza e constituição humana.

Enfim, distinção importante, um conceito de amor não mais definido nos princípios teológicos tomistas (em que os homens trazem uma justiça inata ou "gravada no coração", e com ela a necessidade de obedecer), mas no jusnaturalismo ensinado em Coimbra, após a reforma de $1772 .{ }^{9}$ Destacamos justamente este ponto em Burlamaqui, que possibilita a retomada de sua teoria do direito natural no reino português: uma teoria política em que

9 Estamos, neste ponto, de acordo com o trabalho de José da Silva Dias. O historiador português sustenta uma distinção entre um direito natural tomista e o jusnaturalismo admitido com reforma universitária de 1772. Para Dias, os teólogos espanhóis do século XVI recuperam as noções tomistas ao conceberem uma teoria do direito natural - como o fez Suarez. Também os jesuítas Las Casas e Antonio Vieira se fundamentam nestes conceitos, consultando diretamente o texto de Solorzano Pereira (De iure Indiarum). Em contrapartida, os juristas portugueses de fins dos Setecentos e início dos oitocentos estabeleceram um jusnaturalismo com categorias da "escola pufendorfio-wolffiana". Cf. Dias, 1982, p.76-7. Sobre a fundamentação tomista de Suarez vide o estudo notório Skinner, 1996. cap. 14. 
o amor não é um afeto concebido como oposto à razão, mas produzido por ela como um sentimento de imperiosa sujeição, que torna imprescindível obedecer a uma vontade superior. Se o homem faz uso da sua razão para compreender a sua natureza e a constituição atual, quando deduz destes as leis naturais, estabelece uma justiça. Contudo, esta desvinculação da formulação teológica de jusnaturalismo não implicou na adoção de um "jusnaturalismo ateu" ou mesmo dessacralizador. Pois simultaneamente se reelabora um princípio do jusnaturalismo proposto por Suarez: a obrigação política como reafirmação temporal da vontade de Deus, mas suas leis são internas à natureza humana. Em função das leis naturais, o legislador estabelece não apenas as leis civis, mas também seu respeito a Deus. Obedecendo às leis naturais, os homens se sujeitam ao supremo poder de Deus e estas mesmas leis fundamentam o poder do soberano temporal (o monarca). O entendimento produz o sentimento de amor e de respeito que obriga o homem a obedecer ao Rei, e com ele amar a Deus. Propõe-se aqui uma moralidade religiosa, mas também a afirmação de uma vontade superior como soberania: o que fundamenta aquela moralidade e esta soberania é o conceito de obrigação. Assim, os princípios morais expostos em Burlamaqui permitem esta superposição entre religião e o jusnaturalismo moderno em Portugal.

OLIVEIRA, Eduardo Romero de. Ethics in Jean Burlamaqui and the teaching of natural right at Coimbra. Trans/Form/Ação, (São Paulo), v.30(1), 2007, p.81-100.

- ABSTRACT: This study focus on the work of Jean Burlamaqui, Principes du droit naturel, which has been used in the teaching of philosophy in Portugal, about 1770. The main moral notions of Burlamaqui's theory of natural law are exposed in this work with the purpose of emphasize its rule to constitute the preconceptions for a Portuguese political reflection.

- KEYWORDS: ethics, law natural, Jean Burlamaqui, Portugal (1750-1777).

\section{Referência bibliográfica}

ABRIL, Vidal. "Ensayo de interpretación". In: SUAREZ, Francisco. De legibus, III: De politica obligatione. Ed. bilíngüe de L. Pereña, V. Abril, C. Baciero. Madri: Consejo Superior de Investigaciones Científicas, 1977.

ANDRADE, Antonio B. Vernei e a cultura de seu tempo. Coimbra: Universidade de Lisboa, 1965.

BURLAMAQUI, Jean. Principes du droit naturel. Edição fac-similada de 1821. Caen: Centre de Philosophie Politique et Juridique, 1989.

CASTELLO, José Aderaldo. O movimento academicista no Brasil (1641-1820/22). v.III, tomo 4. São Paulo: Conselho Estadual de Cultura, 1974. 
CATÁLOGO da Biblioteca da Faculdade de Direito de São Paulo em 1887. São Paulo: Jorge Seckler, 1887.

DIAS, José da Silva. "Pombalismo e teoria política". Lisboa: Cultura. n.1, p.45-114, 1982.

DUFOUR, Alfred. "Jusnaturalisme et conscience historique. La pensée politique de Pufendorf ". Cahiers de phisolophie politique et juridique. Caen, n.11, p.103, 1988.

FALCON, Francisco Calazans. A época pombalina. São Paulo: Ática, 1982.

GOYARD-FABRE, Simone. "Lex deux jusnaturalismes ou l'inversion des enjeux politiques ". Cahiers de philosophie politique et juridique, Caen, n.11, p.29-30, 1988.

LEIS do Império do Brazil de 1827. Rio de Janeiro: Typografia. Nacional, 1878.

MÊREA, Paulo. "Lance de olhos sobre o ensino de direito (cânones e leis) desde 1772 até 1804". Boletim da Faculdade de Direito da Universidade da Coimbra. Coimbra, v.33, p.187-214, 1957. 1917.

NASCIMENTO, Milton Meira. Figuras do corpo político. Tese (Livre-docência em Filosofia) - Faculdade de Filosofia, Letras e Ciências Humanas, Universidade de São Paulo, São Paulo, 2000.

PEREIRA, José Esteves. Silvestre Pinheiro Ferreira: o seu pensamento político, Coimbra: Universidade de Coimbra, 1974.

RIBEIRO, Renato Janine. Ao leitor sem medo, São Paulo: Brasiliense, 1984.

. "A filosofia política na história". Filosofia Política, n.2. Porto Alegre: LPM, 1985.

ROUSSEAU, Jean Jacques. Do Contrato Social. Tradução de Lourdes Santos Machado. 3.ed. São Paulo: Abril, 1983.

SILVA, José de Seabra da. Dedução Cronológica e Analítica. Lisboa: Manuel Menescal da Costa, 2v. 1768.

SKINNER, Quentin. As fundações do pensamento político moderno. Tradução de Renato Janine Ribeiro e Laura Teixeira Motta. São Paulo: Companhia das Letras, 1996.

SUAREZ, Francisco. De legibus, II: De lege naturali. Edição bilíngüe de Luciano Pereña e Vidal Abril. Corpus Hispanorum de Pace, v.XIII. Madri, Conselho Superior de Investigações Científicas, 1975.

De legibus, VI: De politica obligatione. Edição bilíngüe de Luciano Pereña, Vidal Abril e C. Baciero. Corpus Hispanorum de Pace, v.XVI-XVII. Madri, Conselho Superior de Investigações Científicas, 1979. 